\title{
Mesoscale variability in phytoplankton biomass distribution and photosynthetic parameters in the Canary-NW African coastal transition zone
}

\author{
Gotzon Basterretxea*, Javier Arístegui \\ Facultad de Ciencias del Mar, Universidad de Las Palmas de Gran Canaria, 35017 Las Palmas de Gran Canaria, Spain
}

\begin{abstract}
Pigment distribution and photosynthesis versus irradiance ( $\mathrm{P}-\mathrm{E}$ ) responses in the mixed layer (ML) and in the chlorophyll maximum (CM) were examined in the coastal transition zone (CTZ) between the NW African coastal upwelling and the Canary Islands during August 1993. The sampling included 2 island-generated eddies in the lee of the archipelago and an upwelling filament from the African continental shelf, entrained around a cyclonic eddy about $100 \mathrm{~km}$ width. Chlorophyll $a$ and P-E parameters $\left(\alpha, P_{\mathrm{m}}\right)$ showed regional differences reflecting changes in the water column structure and phytoplankton species composition. The deep CM shoaled from $\sim 100$ to $\sim 10 \mathrm{~m}$ as the African shelf was approached, and there was a clear offshore-onshore transition in the vertically integrated chlorophyll distribution and P-E responses related to the upwelling front. CM oceanic samples presented high $\alpha$ $\left(0.020\right.$ to $\left.0.042 \mathrm{mg} \mathrm{C} \mathrm{mg}^{-1} \mathrm{chl} \mathrm{h} \mathrm{h}^{-1}\left[\mu \mathrm{mol} \mathrm{m}^{-2} \mathrm{~s}^{-1}\right]^{-1}\right)$ and photoinhibition, indicating adaptation to low irradiance. Differences between $C M$ and $M L$ in P-E responses decreased in the vicinity of the upwelling until they eventually became indistinguishable in a well-mixed station on the continental shelf. Island-generated eddies affected mainly the productivity and chlorophyll distributions at the deep CM. Nutrient input in the eddy center resulted in an increase of $\alpha$ in the CM to the level of the upwelling samples $\left(-0.053 \mathrm{mg} \mathrm{C} \mathrm{mg}^{-1} \mathrm{chl} \mathrm{h}^{-1}\left[\mu \mathrm{mol} \mathrm{m} \mathrm{m}^{-2} \mathrm{~s}^{-1} \mathrm{f}^{-1}\right)\right.$. On the basis of the mesoscale variability in the physical structure of the water column and the vertical distribution of chlorophyl, the CTZ was divided into 4 subregions with characteristic photosynthetic parameters. Average integrated production in these areas varied from $\sim 100 \mathrm{mg} \mathrm{C} \mathrm{m}^{-2} \mathrm{~d}^{-1}$ in the most oligotrophic subregion to more than $5000 \mathrm{mg} \mathrm{C} \mathrm{m} \mathrm{C}^{-2}$ in the upwelling zone. The range of variation in the photosynthetic parameters in this CTZ was of the same magnitude as ranges observed in basin-scale studies of the Atlantic. Integrated production estimates are also in the lower and higher extremes of the observed values in the ocean. Our results highlight the importance of addressing the variability of the photosynthetic parameters in coastal upwelling-open ocean transition zones in order to model primary production at regional scales.
\end{abstract}

KEY WORDS: Phytoplankton · Chlorophyll - Primary production · Coastal transition zone - Filaments · Eddies

\section{INTRODUCTION}

Within the context of global climate change and the role of the ocean as a carbon dioxide sink, one of the main goals of biological oceanography has been the description and understanding of algal carbon fixation at regional and global scales. From the efforts of Koblents-Mishke (1983), based on ecosystem classifi-

\footnotetext{
•E-mail: gotzon,basterretxea@biologia.ulpgc.es
}

cations and ship-based primary production measurements, to the present models based on biogeographical divisions and satellite-obtained ocean color data (e.g. Platt et al. 1988, Longhurst 1995, Sathyendranath et al. 1995), the technique for monitoring phytoplankton photosynthesis has significantly improved. Nevertheless, in global production models, 2 components have changed little: (1) the necessity for in situ observations and (2) the division of the ocean into compartments dependent on a variety of criteria. 
Satellites provide information about sea-surface color fields from which near-surface chlorophyll fields are derived (Gordon et al. 1980). But most complex bio-optical models also require knowledge about depth-resolved optical properties of the water column, and some chlorophyll-specific parameters defining the photoadaptative response of phytoplankton: $P_{m}, \alpha, \beta$ (Platt et al. 1991, Sathyendranath et al. 1995), the absorption cross section $\left(a^{*}\right)$ and quantum yield of phytoplankton (Kiefer \& Mitchell 1983, Bidigare et al. 1987, 1992), or the optimal assimilation efficiency $\left(P_{\text {opt }}\right.$ ) (Behrenfeld \& Falkowski 1997 a) for the biomass-to-production conversion.

An alternative approach is the use of relationships between sea surface temperature (SST) and nitrate concentration and the utilization of nitrate uptake to calculate the $f$-ratio (allochthonous nitrate-based production to total production ratio) as in Eppley \& Peterson (1979) and Sathyendranath et al. (1991). However, this relationship is not useful for most warm oligotrophic water masses where surface concentrations of nitrate are undetectable (Balch \& Byrne 1994).

The complexity of eco-physiological responses in marine systems renders difficult the computation of universally valid relationships between environmental and primary production changes. Consequently, the ocean has generally been divided into relatively homogeneous ecological domains (oceanic-coastal waters, polar-temperate-subtropical-tropical waters, etc.) where a general parameterization can be accomplished. Behrenfeld \& Falkowski (1997b), in a review of primary production models, concluded that differences in estimates of global annual primary production are due to differences in biomass fields and in the selection of the photoadaptative variables but not to the model itself. Hence, a good estimation of primary production requires appropriate selection of the parameters for each region. Moreover, at smaller scales, the presence of different growth and loss characteristics in phytoplankton populations which are spatially heterogeneous means that the approach used at large scales can here lead to ambiguities (Marra 1980). Specific algorithms that account for local peculiarities (i.e. north-south, east-west gradients) or heterogeneities (recurrent or permanent mesoscale structures) should therefore be developed. Finally, links with contiguous regions to avoid excessively fragmented production maps would be desirable.

Coastal transition zones (CTZ) are boundary regions between subtropical gyres and coastal upwelling regions where intense mesoscale variability takes place (Kosro et al. 1991, Strub et al. 1991, Haynes et al. 1993, Barton et al. 1998). The productivity of these areas is uncertain since their intense variability has frequently not been considered. The development of satellite imagery in the last decades has provided evidence that the boundary between coastal upwelling and open ocean systems is highly irregular. Cold filaments have often been reported in the Canary Current (La Violette 1974, Van Camp et al. 1991, Hernández-Guerra et al. 1993) and other eastern boundary currents (Davis 1985, Flament et al. 1985, Kelly 1985, Shannon et al. 1985, Huyer \& Kosro 1987. Strub et al. 1991, Swenson et al. 1992). These structures transport cold upwelled water from the shelf into the ocean, and their return flow introduces warm offshore waters to the nearshore zone (Mooers \& Robinson 1984). Nutrient distributions and plankton biomass and production are also affected (Traganza et al. 1980, Abbott \& Zion 1985, Abbott et al. 1990, Hood et al. 1991). Most observations have led to speculation that filaments act as vehicles to link rich shelf waters with open ocean oligotrophic waters (Mooers \& Robinson 1984, Rienecker et al. 1985). Nevertheless, uncertainties remain about the origin of filaments and their contribution to seaward transport of coastal water.

Because filaments are relatively persistent and recurrent (e.g. Haynes et al. 1993), they may be especially important to the nutrient and carbon fluxes of coastal transition zones. The horizontal exchange of organic material and nutrients between filament and surrounding offshore waters could sustain high production rates outside the upwelling zone, or, alternatively, nutrient upwelling generated by the filament dynamics could significantly contribute to the offshore productivity (Jones et al. 1991).

In the present paper we examine the spatial and vertical distribution of phytoplankton biomass and photosynthesis versus irradiance ( $P$-E) parameters, in a region including the Canary Islands and the nearby NW African Upwelling (NWAU). The transition from the rich coastal upwelling waters to the offshore oligotrophic system covers a region with distinct but closely linked physical and biological characteristics. Vertical stability promoted by thermal stratification, and consequently vertical transport of nutrients, varies from offshore to shelf waters but also varies in relation to mesoscale structures. Recent work has provided evidence of the importance of local mesoscale processes in phytoplankton biomass distribution and production in the Canary Islands (e.g. Arístegui et al, 1997). Knowledge of the effects of these mesoscale forcing functions on biomass accumulation and production is of critical importance when estimating regional and global carbon fixation rates.

\section{METHODS}

Field sampling. The observations reported in this paper were carried out during 4 to 27 August 1993 on 
board BIO 'Hespérides'. The area under study covered the transition zone between the NWAU and offshore waters of the Canarian Archipelago. A transect across the islands to the African shelf was followed by a mesoscale survey of a coastai filament entrained around a cyclonic eddy and an adjacent island-generated eddy (Fig. 1). The eddy position was traced with lagrangian drifters (Barton et al. 1998) and sampled twice (C and D, Fig. 1) over an interval of $5 \mathrm{~d}$. At the center of the eddy (Stn 174) a 24 h sampling was carried out.

CTD data were obtained at each station using a Sea Bird SBE-911 plus probe mounted on a 24 bottle rosette equipped with 121 Niskin bottles. A Sea Tech fluorometer was attached to the system. Data from the CTD sensors were calibrated against reversible thermometer readings and salinity analyses (Autosal 2000) of discrete samples. The in situ fluorometer was calibrated with samples collected at 6 to 8 depths within the upper $100 \mathrm{~m}$ of the water column. For this, $500 \mathrm{ml}$ samples were filtered through Whatman GF/F fiberglass filters and extracted overnight in $10 \mathrm{ml}$ of $90 \%$ acetone at $4{ }^{\circ} \mathrm{C}$ in the dark. For size fractionation, the same volume was filtered through $2 \mu \mathrm{m}$ Millipore polycarbonate filters. Fluorescence before and after acidification was measured with a Turner Designs bench fluorometer (Holm-Hansen et al. 1965), calibrated with pure chlorophyll a (Sigma Chemical Corp.). Underwater scalar photosynthetically available radiation (PAR) profiles were measured using a QSP-200 sensor (Biospherical) and a QSR-240 sensor for on deck referencing.
Chlorophyll transport was calculated from ADCP records (see Barton et al. 1998) as in Jones et al. (1991). To calculate the transport $J$, the flux over an area centered on the grid point $i, j$, was integrated:

$$
\begin{gathered}
J=\sum_{i, j} J_{i, j} \\
J_{i, j}=\vec{V}_{i, j} C_{i, j} L_{x} L_{z}
\end{gathered}
$$

where $\vec{v}_{i, j}=$ velocity perpendicular to a transect plane at the grid point; $C_{i, j}=$ concentration of chlorophyll at grid point $i, j ; L_{x}, L_{z}=$ length of the box around grid point $i, j$ in the horizontal and vertical directions, respectively.

Primary production. Samples for primary production experiments were taken at 2 depths generally corresponding to the mixed layer (ML) and to the chlorophyll maximum (CM). All production stations were sampled around local noon to avoid diel variations of photosynthetic parameters (MacCaull \& Platt 1977). P-E curves were performed in incubators containing 23 culture flasks $(80 \mathrm{ml})$, where a light gradient up to $\sim 1900 \mu \mathrm{mol} \mathrm{m} \mathrm{m}^{-2} \mathrm{~s}^{-1}$ was created using a halogen lamp as a light source. Neutral density filters were used to attenuate the light intensity in the incubator. Light in each bottle was measured with a quantum scalar irradiance meter QSL-100 (Biospherical Co.), and 7 to $14 \mu \mathrm{Ci}$ of ${ }^{14} \mathrm{C}$-labeled sodium bicarbonate solution was added to each bottle. In situ temperatures were reproduced inside the incubator with a cooling bath to within $\pm 0.1^{\circ} \mathrm{C}$. The added activity was estimated at the beginning of the incubation by counting $1 \mathrm{ml}$ of solution in a vial with Protosol (NEN) and scintillation

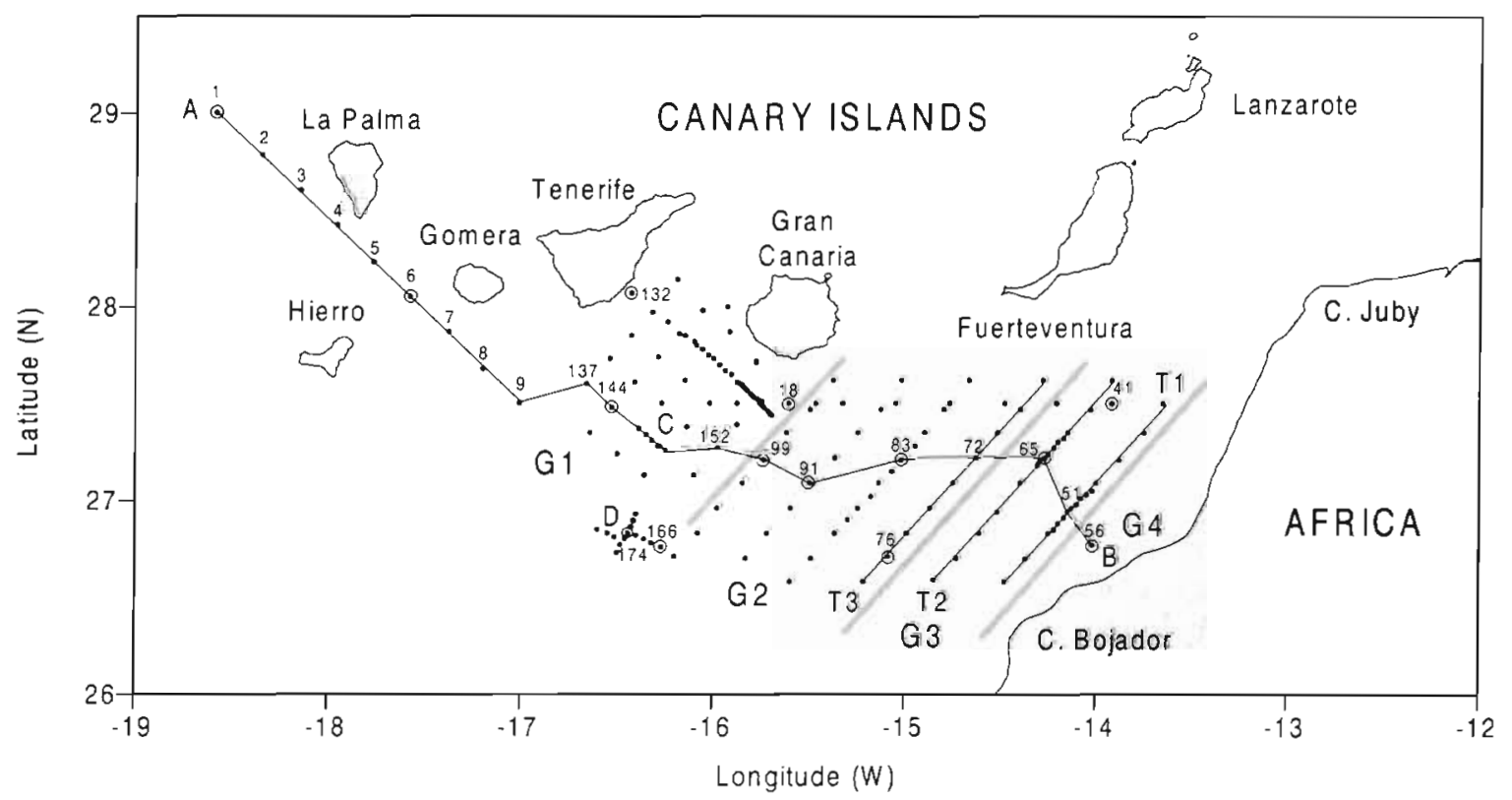

Fig. 1. Map of stations. C and D mark the position of an island-generated eddy in 2 surveys. A to B marks the position of the transect represented in Fig. 3. T1, T2 and T3 are the transects for which chlorophyll transport was calculated (Table 1). The region was divided into zones G1, G2, G3 and G4 for primary production estimations 
cocktail. After $3 \mathrm{~h}$ of incubation, samples were filtered using low vacuum pressure ( $<0.3$ bar) onto glass fiber filters (Whatman GF/F, $25 \mathrm{~mm}$ ) and acidified with $1 \mathrm{ml}$ of $2 \mathrm{~N} \mathrm{HCl}$ for $\sim 18 \mathrm{~h}$ to drive off inorganic carbon. Radioactivity was counted on board in a Beckman scintillation counter using Aquasol-II cocktail. An external standard was used for quench correction. Dark fixation was subtracted from illuminated bottle counts.

Chlorophyll-specific photosynthetic parameters $\alpha$, $P_{\mathrm{m}}$ and $\beta$ were fitted to standardized production values by non-linear regression fitting of the expression by Platt et al. (1980):

$$
P(E)=P_{s}\left(1-e^{\left(-\alpha E / P_{s}\right)}\right)\left(e^{\left(\beta E / P_{s}\right)}\right)
$$

where $P(E)\left({\mathrm{mg} \mathrm{C} \mathrm{mg}^{-1} \mathrm{chl} \mathrm{h}}^{-1}\right)$ is the instantaneous production rate normalized to chlorophyll at irradiance $E\left(\mu \mathrm{mol} \mathrm{m}{ }^{-2} \mathrm{~s}^{-1}\right), \alpha$ is the initial slope of the P-E curve at limiting light levels ( $\mathrm{mg} \mathrm{C} \mathrm{mg}^{-1} \mathrm{chl} \mathrm{h}^{-1}$ [ $\mu \mathrm{mol} \mathrm{m} \mathrm{m}^{-2}$ $\left.\mathrm{s}^{-1} \mathrm{l}^{-1}\right), \beta$ is a parameter to characterize photoinhibition ( $\mathrm{mg} \mathrm{C} \mathrm{mg}^{-1} \mathrm{chl} \mathrm{h}{ }^{-1}\left[\mu \mathrm{mol} \mathrm{m}{ }^{-2} \mathrm{~s}^{-1}\right\}^{-1}$ ), and $P_{\mathrm{s}}$ is the potentially maximum light-saturated rate of photosynthesis under conditions of no photoinhibition. In the absence of photoinhibition this expression can be reduced to the equation of Webb et al. (1974):

$$
P(E)=P_{\mathrm{m}}\left(1-\mathrm{e}^{\left(-\alpha E / P_{m^{\prime}}\right)}\right)
$$

where $P_{\mathrm{m}}$ and $P_{\mathrm{s}}$ can be related by the expression after Platt et al. (1980).

$$
P_{\mathrm{m}}=P_{\mathrm{s}}(\alpha / \alpha+\beta)(\beta / \alpha+\beta)^{\beta / \alpha}
$$

Integrated production calculations. Daily depthintegrated production rates $(0$ to $100 \mathrm{~m})$ were estimated using measured light attenuation coefficients, surface P-E parameters and chlorophyll data for each station. Daily light variation was calculated assuming a sinusoidal variation of the measured midday surface irradiance. Production estimates based on $2 \mathrm{P}$-E curves (ML and CM) were performed assuming that the surface parameters were constant throughout the ML and decreased or increased linearly from the thermocline to the CM. No correction was made for diel variations of photosynthetic parameters since variations observed in the only diel study were unlikely to be representative of changes at every station.

As most chlorophyll profiles showed subsurface maxima, integrated production values were calculated assuming a non-uniform biomass profile. Hence the data were used to calculate a Gaussian curve from which parameters were derived for calculation of biomass at any depth $(z)$ :

$$
B_{z}=B_{0}+\frac{h}{\sigma \sqrt{2 \pi}} \exp \left[-\frac{1}{2}\left(\frac{z-z_{\mathrm{m}}}{\sigma}\right)^{2}\right]
$$

where $B_{0}$ is the baseline pigment concentration (mg $\mathrm{m}^{-3} \mathrm{j}, \mathrm{z}_{\mathrm{m}}$ is the depth of the chlorophyll maximum (m), $\sigma$ the width of the peak $(\mathrm{m})$ and $h /(\sigma \sqrt{2 \pi})$ is the height of the peak ( $h$ units are $\mathrm{mg} \mathrm{m}^{-2}$ ) measured from the baseline (Platt et al. 1991).

The light profile was calculated as follows: maximum photon flux at noon on the sea surface was obtained from averaged on deck records. Surface irradiance was assumed to vary as a sine function over the day. Losses of irradiance by reflectance at the sea surface were calculated from the values of Austin (1974) for $4 \mathrm{~m} \mathrm{~s}^{-1}$ winds. Light at depth $z$ was obtained from $E_{z}=$ $E_{z-1} \exp (-K \Delta z)$, where the average light attenuation coefficient $K\left(\mathrm{~m}^{-1}\right)$ was computed from in situ measurements. Finally daily-integrated production values $\left(P_{\text {Int }}\right)$ were obtained by double integration over daylength and depth.

\section{RESULTS}

\section{Hydrographic structure and distribution of phytoplankton biomass}

The general hydrographic pattern during the cruise has been thoroughly described in Barton et al. (1998) and Navarro-Pérez \& Barton (1998). An upwelling filament was situated between Cabo Juby and Cabo Bojador extending about $150 \mathrm{~km}$ seaward from the continental shelf, reaching the vicinity of Gran Canaria. At its offshore limit, the filament was entrained around a wide oval-shaped cyclonic eddy with its major axis aligned with the prevailing current. At depths below the mixed layer, the eddy presented a clear signal of low temperatures (Fig, 2).

Southwest of Gran Canaria, the signal of a smaller cold-core eddy was also evident. The eddy drifted southwestward at a speed of about $0.1 \mathrm{~m} \mathrm{~s}^{-1}$ (Barton 1994b) with a trajectory and position consistent with previous descriptions of island-generated eddies in the area (Arístegui et al. 1994).

Chlorophyll concentrations ranged from about $0.05 \mathrm{mg} \mathrm{m}^{-3}$ in the oceanic areas to more than $3 \mathrm{mg} \mathrm{m}^{-3}$ over the African shelf. A map of integrated ( 1 to $100 \mathrm{~m}$ ) chlorophyll distribution (Fig. 2) reveals highest values over the continental shelf in the upwelling zone but rapidly decreasing in the offshore direction. Low chlorophyll values appear in the center of the filament eddy, while a localized maximum was observed on its southern flank (see 'Discussion').

With the aim of quantifying the importance of the filament as a mechanism of offshore transport of phytoplankton biomass, we calculated the chlorophyll transport based on ADCP records (Barton et al. 1998, Navarro-Perez \& Barton 1998) across Transects T1, T2 and T3 (Fig. 1) as in Jones et al. (1991). Although the biomass signal along the jet rapidly disappeared, a net 


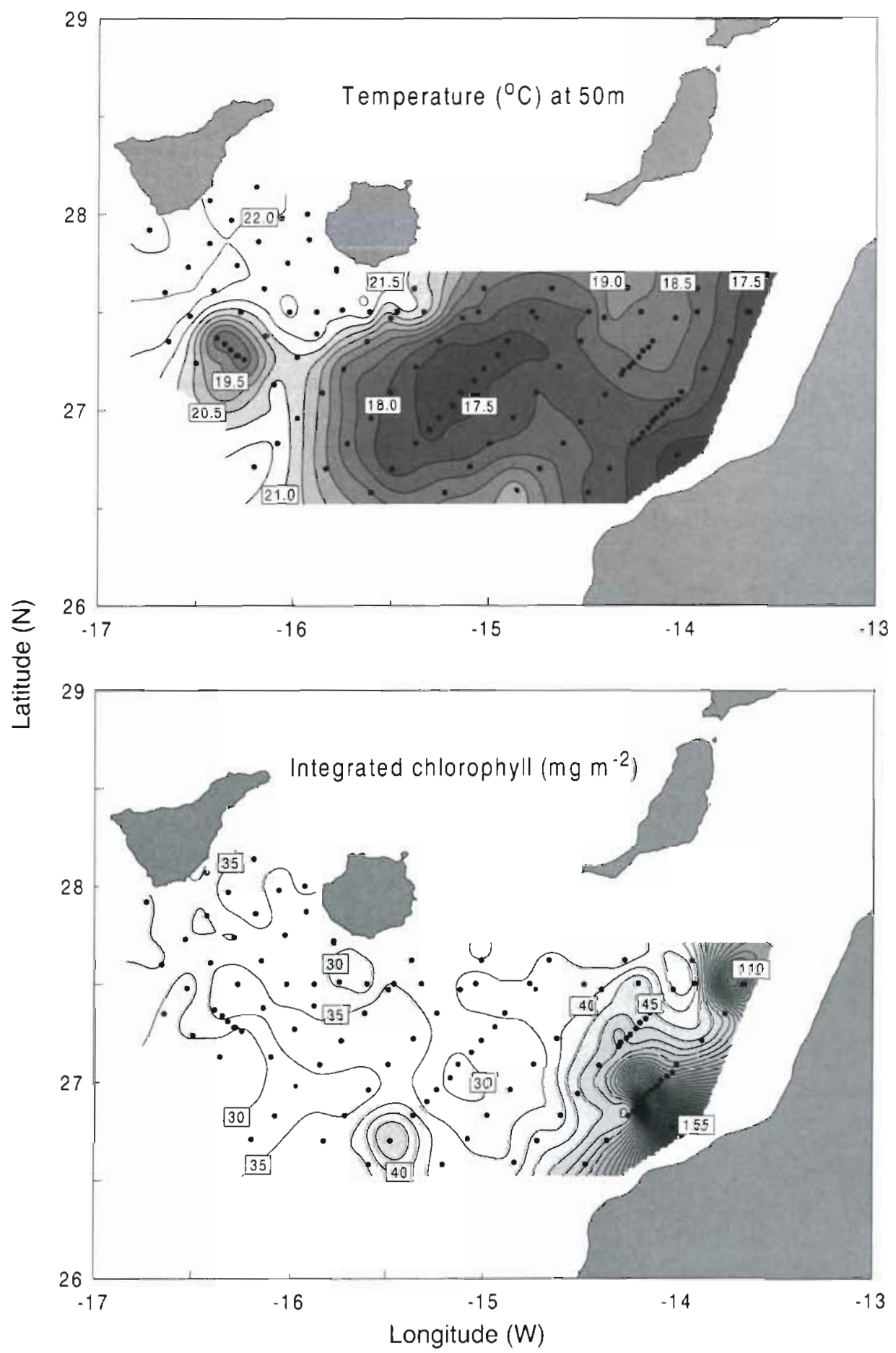

Fig. 2. Maps of temperature at $50 \mathrm{~m}$ depth (upper panel) and integrated chlorophyll (lower panel). Notice the presence of 2 cold-core eddies in the map of temperature. The larger one is associated with the upwelling filament and the smaller with Gran Canaria

seaward transport was expected in the section nearest to shore, where both current intensity and biomass are higher. Nevertheless, results show (Table 1) that even in the surface layer $(0$ to $50 \mathrm{~m})$, where the signal of the filament is stronger, net transport is consistently shorewards.

A transect across and south of the islands (Fig. 3a) shows high variability downstream of the archipelago. 
Table 1. Chlorophyll transport $\left(\mathrm{g} \mathrm{s}^{-1}\right)$ across Transects T1, T2 and $\mathrm{T} 3$

\begin{tabular}{|lcrcc|}
\hline Transect & $\begin{array}{c}\text { Depth } \\
\text { range }(\mathrm{m})\end{array}$ & Seaward & Shoreward & Difference \\
\hline T1 & $0-50$ & 38 & 96 & -57 \\
& $0-100$ & 181 & 531 & -350 \\
T2 & $0-50$ & 135 & 403 & -268 \\
& $0-100$ & 307 & 608 & -301 \\
T3 & $0-50$ & 45 & 94 & -49 \\
& $0-100$ & 79 & 227 & -148 \\
\hline
\end{tabular}

Surface temperatures in the surface layer increase from $17.5^{\circ} \mathrm{C}$ on the African shelf to $22^{\circ} \mathrm{C}$ offshore. The upper part of the water column on the continental shelf is well mixed, while a sharp thermocline, progressively deeper, appears westwards. This trend is disrupted by the presence of mesoscale features leeward of the islands. Two temperature domes, presumably corresponding to 2 cold-core eddies, are observed southwest of the islands of La Gomera and Gran Canaria. The latter eddy is more intense (>50 m uplift) and exaggerated by the steep isothermal decline on its western side. This isoline deepening is caused by an adjacent anticyclonic structure observed in AVHRR images in the vicinity of Tenerife (Barton et al. 1998). West of La Palma (Stn 3) a third dome affecting the upper $80 \mathrm{~m}$ is also observed. The deep CM shoals in a west-east direction from 90 to $110 \mathrm{~m}$ at the westernmost stations to $10 \mathrm{~m}$ over the continental shelf. Intense doming due to eddies produces the elevation of the deep CM, as seen in the periphery of the eddy of Gran Canaria. This effect has been extensively discussed by Arístegui et al. (1997).
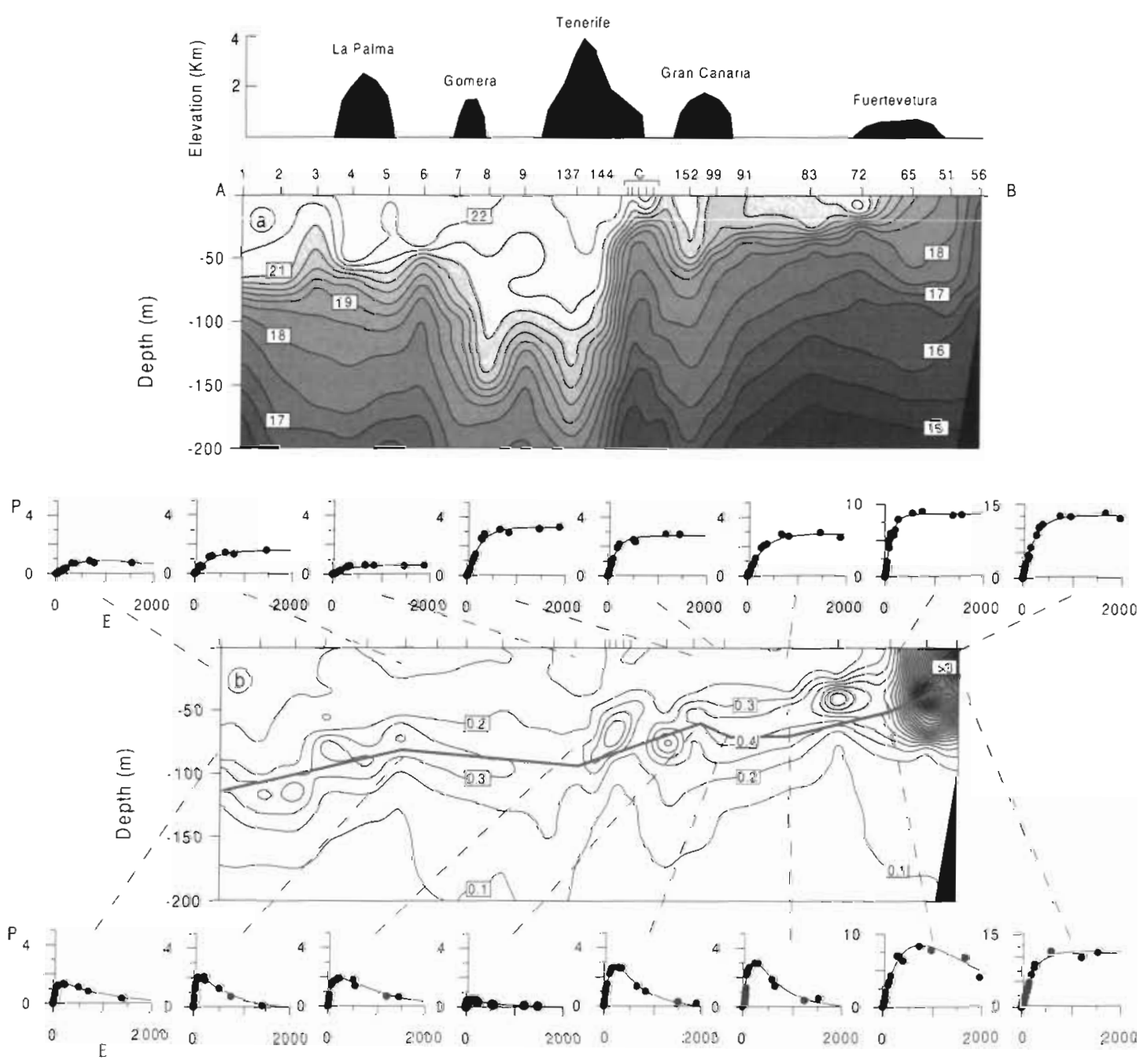

Fig. 3. Contour plots of temperature $\left({ }^{\circ} \mathrm{C}\right.$; middle panel, a) and chlorophyll $\left(\mathrm{mg} \mathrm{m}^{-3}\right.$; lower panels, b) along Transect $\mathrm{A}-\mathrm{B}$ (dashed lines indicate the location and depth of P-E experiments; grey line marks the depth of $1 \%$ surface irradiance). Axes for P-E curves

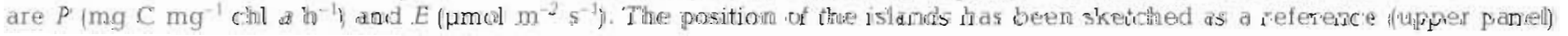




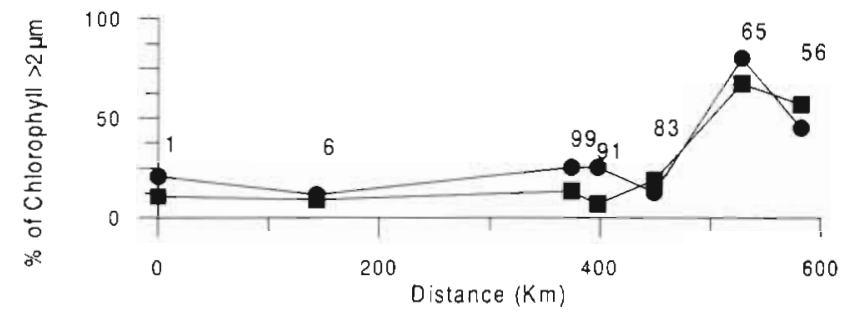

Fig. 4. Percentage of chlorophyll $a>2 \mu \mathrm{m}$ in a $\mathrm{W}$-E transect in the mixed layer (๑) and in the chlorophyll maximum (ם)

Although the upwelling filament and its terminal eddy extend $100 \mathrm{~km}$ offshore to Stn 99, high surface chlorophyll values ( $>1 \mathrm{mg} \mathrm{m}^{-2}$ ) are restricted to the stations in the upwelling area. Stn 65 is placed in the boundary between high-pigment-content upwelled waters and waters in the filament where values higher than those offshore are encountered only in the deep CM. A shift in the community structure also occurs at this point. Size fractionation of chlorophyll reveals picoplankton as the dominant size fraction outside the upwelling, accounting for 75 to $88 \%$ of the total biomass (Fig. 4). This percentage dramatically changes in upwelled waters and particularly in the front between both water masses (Stn 65) where large cells ( $>2 \mu \mathrm{m}$ ) dominate $(80 \%)$. At this station a shallow thermocline (23 $\mathrm{m}$ depth) is already visible.

\section{Primary production}

P-E response curves along Transect $A-B$ (Fig. 3b, Table 2) display a clear offshore-onshore transition. Two trends in the phytoplankton light response are particularly clear across the CTZ: (1) there is an increase in the magnitude of the P-E parameters as the nutrient-rich upwelling waters are approached and (2) the photosynthetic responses in the ML and CM become progressively alike as mixing increases towards the coastal upwelling. ML and CM parameters for the station on the continental shelf (Stn 56), where nutrient concentrations are high (almost $4 \mu \mathrm{M}$ at $10 \mathrm{~m}$ ), are similar and do not present significant photoinhibition. Both parameters are amongst the highest measured (average $P_{\mathrm{m}}$ and $\alpha, 12.11 \pm 0.9 \mathrm{mg} \mathrm{C} \mathrm{mg}^{-1} \mathrm{chl} \mathrm{h}^{-1}$ and $0.052 \mathrm{mg} \mathrm{C} \mathrm{mg}^{-1} \mathrm{chl} \mathrm{h}{ }^{-1}\left[\mu \mathrm{mol} \mathrm{m} \mathrm{m}^{-2} \mathrm{~s}^{-1}\right]^{-1}$, respectively). By contrast, in open ocean waters differences between ML and CM parameters increase. Most CM samples exhibit higher $\alpha$ values and photoinhibition, indicating enhanced photosynthetic efficiency and adaptation to low irradiances in deep phytoplankton assemblages. The light adaptation parameter $E_{\mathrm{k}}\left(P_{\mathrm{m}} / \alpha\right)$ averages $267 \pm 72$ and $93 \pm 49 \mu \mathrm{mol} \mathrm{m}^{-2} \mathrm{~s}^{-1}$ in the ML and $\mathrm{CM}_{1}$ respectively. Of particular interest are the parameters at Stns 76 and 166 (Table 2). The former is located in the southern boundary of the filament. A

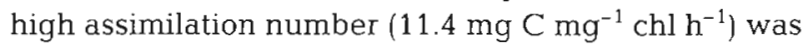
measured in the ML at this station, while at the deep CM, $P_{\mathrm{m}}$ is closer to the values observed in the rest of the filament structure. Conversely Stn 166, located in the island-generated eddy, shows anomalous high photosynthetic values in the CM sample $\left(P_{\mathrm{s}}=6.94 \mathrm{mg}\right.$

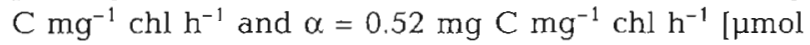
$\mathrm{m}^{-2} \mathrm{~s}^{-1} \mathrm{~J}^{-1}$ ). Similar $\alpha$ values in CM samples were measured only in the cyclonic eddy southwest of La Gomera (Stn 6) and over the African shelf (Stn 56) Nitrate concentrations at the subsurface sampling depth at these 3 stations were above detectable levels $(>0.5 \mu \mathrm{M})$, an indication of nutrient-rich water upwelling or nutricline uplifting.

P.E parameters estimated for the ML at the $24 \mathrm{~h}$ station in the center of the eddy (Stn 174) displayed similar midday values $\left(\alpha=0.008 \mathrm{mg} \mathrm{C} \mathrm{mg}^{-1} \mathrm{chl} \mathrm{h}^{-1}\right.$ [ $\mu \mathrm{mo}$ ] $\mathrm{m}^{-2} \mathrm{~s}^{-1} \mathrm{~J}^{-1}$ and $P_{\mathrm{m}}=2.88 \mathrm{mg} \mathrm{C} \mathrm{mg}^{-1} \mathrm{chl} \mathrm{h}{ }^{-1}$ ) to the nearby Stn 166 , placed in a more marginal zone. There was a significant diurnal variation in light-saturated and light-limited photosynthesis $(\mathrm{CV}=0.54$ and 0.31$)$, with maximum rates close to midday, but $\alpha$ presented

Table 2. P-E curve parameters $\alpha\left(\mathrm{mg} \mathrm{C} \mathrm{mg} \mathrm{m}^{-1} \mathrm{chl} \mathrm{h}^{-1}\left[\mu \mathrm{mol} \mathrm{m} \mathrm{m}^{-2}\right.\right.$ $\left.\left.\mathrm{s}^{-1}\right]^{-1}\right), P_{\mathrm{s}}\left(\mathrm{mg} \mathrm{C} \mathrm{mg}^{-1} \mathrm{chl} \mathrm{h}{ }^{-1}\right), \beta\left(\mathrm{mg} \mathrm{C} \mathrm{mg}^{-1} \mathrm{chl} \mathrm{h}{ }^{-1}\left[\mu \mathrm{mol} \mathrm{m}{ }^{-2}\right.\right.$ $\left.\mathrm{s}^{-1} \mathrm{~J}^{-1}\right), P_{\mathrm{m}}\left(\mathrm{mg} C \mathrm{mg}^{-1} \mathrm{ch} \mathrm{h}^{-1}\right)$ and sampling depth $(\mathrm{m})$

\begin{tabular}{|c|c|c|c|c|c|}
\hline Stn & Depth & $\alpha$ & $P_{5}$ & $\beta$ & $P_{\mathrm{m}}$ \\
\hline 1 & 20 & 0.003 & 2.61 & 0.0017 & \\
\hline 6 & 15 & 0.005 & & & 1.62 \\
\hline 18 & 15 & 0.008 & & & 1.75 \\
\hline 41 & 10 & 0.015 & & & 4.16 \\
\hline 56 & 3 & 0.053 & & & 13.02 \\
\hline 65 & 20 & 0.075 & & & 9.08 \\
\hline 76 & 10 & 0.012 & 11.42 & 0.0071 & \\
\hline 83 & 10 & 0.011 & & & 3.05 \\
\hline 91 & 10 & 0.016 & & & 2.89 \\
\hline 99 & 10 & 0.014 & & & 3.53 \\
\hline 132 & 10 & 0.009 & 5.30 & 0.0025 & \\
\hline 144 & 10 & 0.003 & & & 0.68 \\
\hline 166 & 10 & 0.007 & & & 2.81 \\
\hline 1 & 80 & 0.023 & 1.93 & 0.0020 & \\
\hline 6 & 80 & 0.055 & 3.11 & 0.0053 & \\
\hline 18 & 80 & 0.020 & 2.27 & 0.0025 & \\
\hline 41 & 30 & 0.027 & 5.81 & 0.0047 & \\
\hline 56 & 20 & 0.052 & & & 11.21 \\
\hline 65 & 40 & 0.035 & 8.72 & 0.0105 & \\
\hline 76 & 40 & 0.034 & 5.51 & 0.0047 & \\
\hline 83 & 50 & 0.042 & 5.87 & 0.0106 & \\
\hline 91 & 70 & 0.035 & 5.87 & 0.0109 & \\
\hline 99 & 70 & 0.020 & 0.60 & 0.0012 & \\
\hline 132 & 60 & 0.023 & 3.85 & 0.0013 & \\
\hline 144 & 75 & 0.032 & 2.82 & 0.0026 & \\
\hline 166 & 60 & 0.052 & 6.94 & 0.0106 & \\
\hline
\end{tabular}




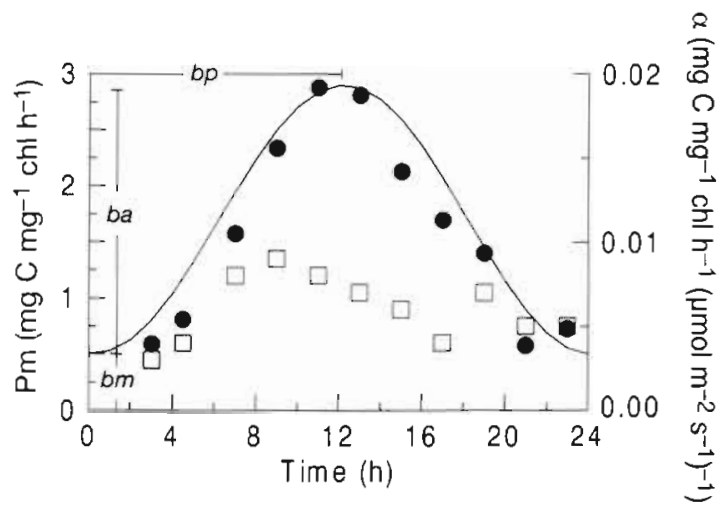

Fig. 5. Plots of $P_{\mathrm{m}}(\bullet)$ and $\alpha$ (口) over time for a diel cycle at Stn 174. A sine curve

$$
P_{r a}(t)=b_{\mathrm{m}}+b_{\mathrm{a}} 2^{-n}\left[1+\cos (2 \pi / 24)\left(t-b_{\mathrm{p}}\right)\right]^{n}
$$

(MacCaull \& Platt 1977) for $n=1$ has been overlaid as a reference

some random oscillations (Fig. 5). Nevertheless, these variations should be carefully interpreted since there is evidence that prolonged ( $>1$ h) incubations may be biased by photoadaptative responses occurring on time scales of the same order or shorter than the incubation time that result in P-E variability (Lewis \& Smith 1983).
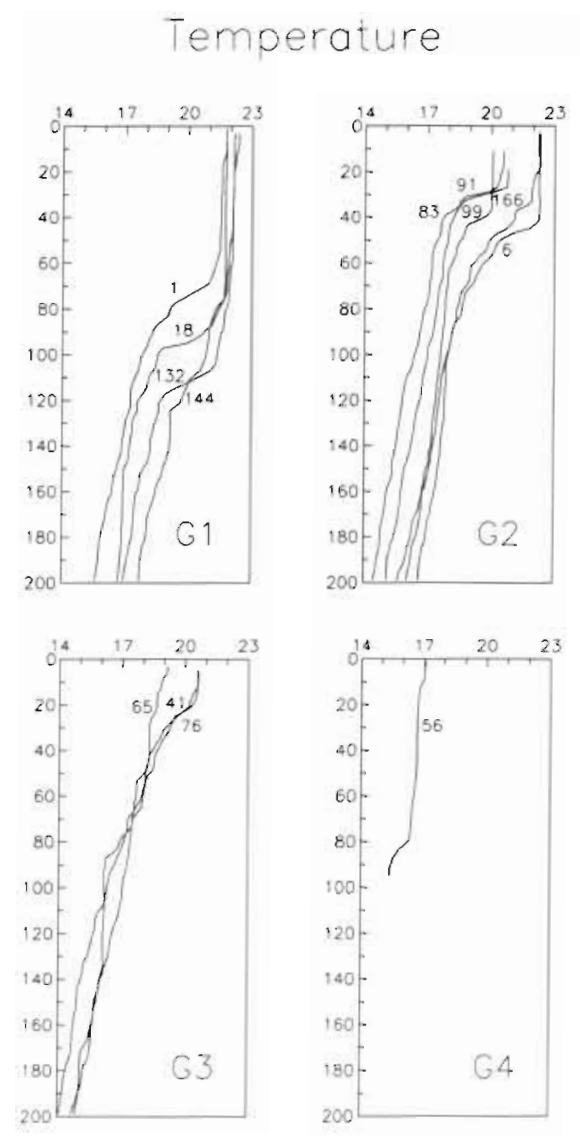

With the aim of attaining general parameters to be used in a regional production model, we have grouped the stations where P-E experiments were carried out into 4 groups, according to the thermal structure of the water column and to the vertical distribution of phytoplankton biomass (Fig. 6). G1 includes the stations representative of offshore conditions with a deep CM around $100 \mathrm{~m}$ depth. This distribution is typical of warm offshore regions (Venrick et al. 1973, Herbland \& Voituriez 1979, Cullen \& Eppley 1981). Stations in the offshore extension of the filament or in the islandgenerated eddies (Stns 6 and 166) are included in G2. The latter present a thermocline structure similar to the waters of the filament although surface temperatures $\left(>22^{\circ} \mathrm{C}\right)$ are in the range of offshore waters. G3 and G4 include stations in the upwelling front and on the continental shelf. Stn 76 shares characteristics with G2 and G3. Although it is far from the shelf, the structure of the water column, the vertical pigment distribution and the temperature-salinity characteristics at this location (Fig. 7) make it conform most to G3. Nevertheless, some other characteristics like the percentage of cells $>2 \mu \mathrm{m}(13 \%$ at Stn 76 and $49 \%$ at Stn 41$)$ or the relation between the $1 \%$ light depth, deep CM
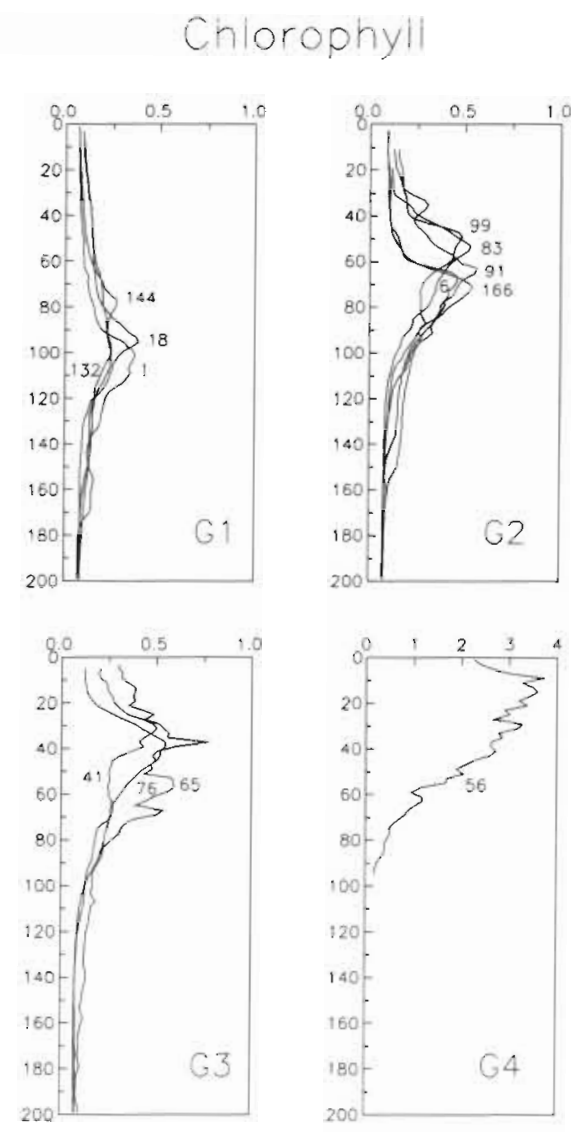

Fig. 6. Temperature $\left({ }^{\circ} \mathrm{C}\right)$ and chlorophyil profiles $\left(\mathrm{mg} \mathrm{m}^{-3}\right)$ for different groups of stations (see 'Results, Primary production' for group descriptions) 


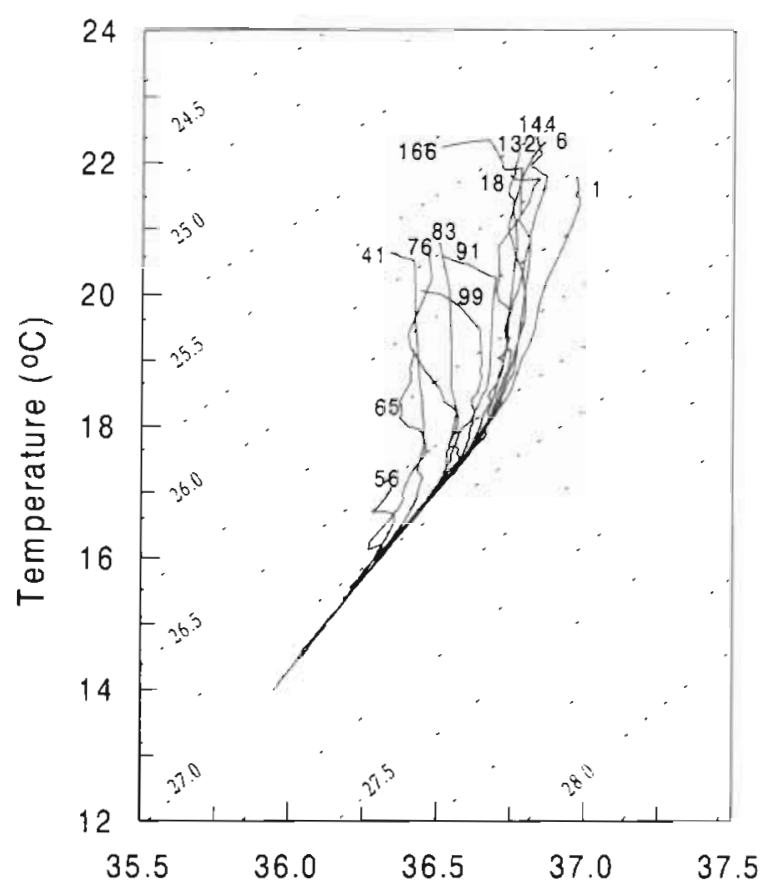

Salinity

Fig. 7. Temperature-salinity characteristics $(0$ to $200 \mathrm{~m})$ of P-E stations

and thermocline depths (Fig. 8) indicate similarities with the stations in the offshore filament.

Temperature-salinity plots (Fig. 7) reveal that along the CTZ gradient the upwelled water is mixed to varying degrees with offshore waters. The progressive transition in thermo-haline properties is disrupted by the gap between the stations placed farther offshore in the filament (Stns 91 and 99) and Stn 18 located only a few kilometers north. This gap separates upwellinginfluenced waters from offshore and eddy waters.

Tables 3 \& 4 synthesize some characteristics of each of the groups ( $\operatorname{Stn} 76$ has been excluded from averages). Chlorophyll profile parameters show clear differences between groups as result of the progressively sinking chlorophyll maximum depth $\left(z_{\mathrm{m}}\right)$ and the increase of the $1 \%$ light depth $\left(z_{\text {eu }}\right)$ towards oceanic

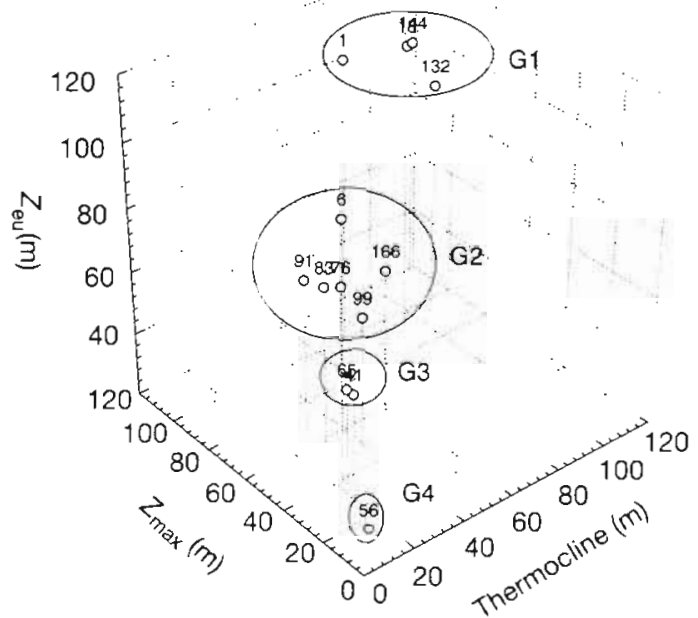

Fig. 8. Plot of grouped $z_{\max }$ (depth of the chlorophyl maximum), $z_{\text {eu }}$ (depth of $1 \%$ PAR) and thermocline depth

waters. In fact, there is a constant relation between these 2 parameters averaged by groups (Fig. 8 ). This is not the case with photosynthetic parameters. Stations affected by island-generated eddies do not fit well in G2 (Table 4) and have been treated as a separate group. Surface parameters in the eddies are in the range of G1, but values in the CM are clearly enhanced. The value of $a$ is similar to that in the coastal upwelling and $P_{\mathrm{s}}$ is in the range of G3.

We calculated daily production rates per unit surface $\left(P_{\text {int }}\right)$ for each of the areas indicated in Fig. 1 (G1, G2, G3 and G4) and for the cyclonic eddies based on ML parameters. Calculations were performed by 4 different methods: (1) averaging estimates of the stations in each region, (2) calculating an average P-E curve for each region and using the measured chlorophyll distribution for each station, (3) averaging the non-uniform biomass curve parameters for each region and applying the measured P-E curve for each station, and (4) using an average P-E curve and an average biomass profile for each region. Results from all 4 methods were very similar and maximum deviations $(\mathrm{CV}<$

Table 3. Integrated chlorophyl ( $\mathrm{chl}_{\mathrm{inti}} \mathrm{mg} \mathrm{m}^{-2}$ ), $1 \%$ light depth $z_{\mathrm{eu}}(\mathrm{m})$, and non-uniform biomass distribution curve fitting parameters $z_{\max }(\mathrm{m}), \sigma(\mathrm{m}), h\left(\mathrm{mg} \mathrm{m}^{-2}\right), B_{0}\left(\mathrm{mg} \mathrm{m}^{-3}\right)$ for each zone ( $\left.\pm \mathrm{SD}\right)$

\begin{tabular}{|c|c|c|c|c|c|c|}
\hline & $\mathrm{Chl}_{1 \mathrm{It}}(0-200 \mathrm{~m})$ & $z_{\mathrm{eu}}$ & $z_{\max }$ & $\sigma$ & $h$ & $B_{0}$ \\
\hline $\mathrm{G} 1(\mathrm{n}=4)$ & $28 \pm 1$ & $103 \pm 8$ & $96 \pm 7$ & $21 \pm 9$ & $9 \pm 2$ & $0.09 \pm 0.01$ \\
\hline $\mathrm{G} 2(\mathrm{n}=5)$ & $33 \pm 7$ & $73 \pm 8$ & $68 \pm 7$ & $19 \pm 7$ & $16 \pm 4$ & $0.09 \pm 0.01$ \\
\hline G3 $(n=2)$ & $41 \pm 13$ & $52 \pm 1$ & $41 \pm 3$ & $27 \pm 0$ & $25 \pm 8$ & $0.09 \pm 0.01$ \\
\hline $\mathrm{G} 4(n=1)$ & $179^{\mathrm{a}}$ & 26 & 22 & 22 & 164 & 0.47 \\
\hline${ }^{\mathrm{a}} 0$ to $95 \mathrm{~m}$ & & & & & & \\
\hline
\end{tabular}


Table 4. Range of P-E parameters in mixed layer (ML) and chlorophyll maximum (CM) samples for each zone; $\alpha$ (mg $C \mathrm{mg}^{-1}$ chl h${ }^{-1}\left[\mu \mathrm{mol} \mathrm{m} \mathrm{s}^{-2} \mathrm{~s}^{-1}\right), P_{\mathrm{m}}\left(\mathrm{mg} \mathrm{C} \mathrm{mg}^{-1} \mathrm{chl} \mathrm{h}^{-1}\right), P_{\mathrm{s}}\left(\mathrm{mg} \mathrm{C} \mathrm{mg}^{-1} \mathrm{chl} \mathrm{h}^{-1}\right)$ and $\beta\left(\mathrm{mg} \mathrm{C} \mathrm{mg}^{-1} \mathrm{chl} \mathrm{h}^{-1}\left[\mu \mathrm{mol} \mathrm{m}^{-2} \mathrm{~s}^{-1}\right]^{-1}\right)$

\begin{tabular}{|c|c|c|c|c|c|}
\hline & $\alpha(\mathrm{ML})$ & $P_{\mathrm{m}}(\mathrm{ML})$ & $\alpha(C M)$ & $P_{\mathrm{s}}(\mathrm{CM})$ & $\beta(C M)$ \\
\hline $\mathrm{Gl}(\mathrm{n}=4)$ & $0.003-0.009$ & $0.60-5.80$ & $0.020-0.032$ & $1.93-3.85$ & $0.0013-0.0026$ \\
\hline$G 2(n=3)$ & $0.011-0.016$ & $2.89-2.53$ & $0.020-0.042$ & $0.60-5.87$ & $0.0012-0.0109$ \\
\hline $\mathrm{G} 3(\mathrm{n}=2)$ & $0.015-0.075$ & $4.16-9.08$ & $0.027-0.035$ & $5.81-7.27$ & $0.0047-0.0105$ \\
\hline Eddies $(\mathrm{n}=2)$ & $0.005-0.007$ & $1.62-2.81$ & $0.052-0.055$ & $3.11-6.94$ & $0.0053-0.0106$ \\
\hline $\mathrm{G} 4(\mathrm{n}=1)$ & 0.053 & 13.02 & 0.052 & 11.21 & 0 \\
\hline
\end{tabular}

$17 \%$ ) occurred in the offshore region (G1). Average estimates varied from 102 to $189 \mathrm{mg} \mathrm{C} \mathrm{m}^{-2} \mathrm{~d}^{-1}$ for zones $\mathrm{G} 1$ and $\mathrm{G} 2,95 \mathrm{mg} \mathrm{C} \mathrm{m}{ }^{-2} \mathrm{~d}^{-1}$ in the eddies, $777 \mathrm{mg} \mathrm{C}$ $\mathrm{m}^{-2} \mathrm{~d}^{-1}$ for $\mathrm{G} 3$ and $5326 \mathrm{mg} \mathrm{C} \mathrm{m} \mathrm{m}^{-2}$ for G4. However, when 2 P-E curves (ML and CM) were used in the calculations (1 for the ML and a linear interpolation below, see 'Methods') estimates for G1 and the eddies dramatically changed $(72 \%$ increment in G1 and $131 \%$ in the eddies).

\section{DISCUSSION}

\section{Phytoplankton distribution and transport}

Physical and biological observations carried out during summer 1993 (the season of strongest trade winds in the area) reveal the presence of intense mesoscale variability in the CTZ of the NW African coast, affecting phytoplankton biomass distribution and primary production rates. Strong wind intensity enhances both coastal upwelling-related phenomena like filaments and island-generated eddy formation (Barton 1994a,b). Under these conditions eddy shedding is a common phenomenon that appears to be produced by the interaction of the islands with the southward flowing Canary Current (Arístegui et al. 1994).

Filaments enhance the exchange between upwelling and open ocean waters since their offshore transport can be significantly larger than Ekman transport (Kostianoy \& Zatsepin 1996, Navarro-Perez \& Barton 1998). In our study, the filament extended approximately $150 \mathrm{~km}$ offshore and then wrapped around a cyclonic eddy of $100 \mathrm{~km}$ diameter, to return shorewards. Chlorophyll distribution, although generally coherent with the temperature field, did not follow the entire path of the filament. Instead, waters with high chlorophyll levels dominated by large cells (>2 $\mu \mathrm{m}$ ) were restricted to the shelf, and to a few stations in the filament jet. Sinking, lack of nutrients, grazirig and losses by turbulent diffusion are possible explanations for phytoplankton decay. Relatively higher concentrations of chlorophyll, which could be indicative of cells sinking below the photic zone, were observed in slope waters and in the anticyclonic eddy south of Tenerife. The general trend of the CM presents a progressive deepening that parallels the enlargement of the euphotic layer.

Brink et al. (1991) suggest that sinking of near-surface water accounts for the rapid warming of surface waters with distance offshore in the filament. Our data show that there is a clear boundary marked by the presence of vertical isotherms indicating mixing. The real transition between the coastal upwelling and the filament takes place at Stn 65 (see temperature-salinity diagram, Fig. 7). Surface chlorophyll decreases by more than $1 \mathrm{mg} \mathrm{m}^{-3}$ in comparison to $\operatorname{Stn} 56$, located $54 \mathrm{~km}$ shorewards, but the percentage of chlorophyll content in large cells is even higher than over the shelf. This effect has been corroborated by HPLC data on the same cruise (Van Lenning pers. comm.) that showed a higher contribution of diatoms to total chlorophyll at Stn 65 ( $\max .96 \%$ ) than over the shelf (max. 87\%), and could be attributed to species succession along the jet. Margalef (1982) suggests a theoretical succession that begins with small cells (flagellates and non-flagellates), continuing with medium-sized diatoms, and finally large-sized diatoms and dinoflagellates. This would explain the higher percentages of large cells observed in the upwelling front (Stn 65). This theory has been argued by Barber \& Smith (1981), who stated that newly upwelled water communities are the midpoint of the ecological sequence, since 3-dimensional circulation along the upwelling determines what will be in the subsurface flow that is upstream of the vertical transport. In any case, this mechanism would only accelerate the community evolution from small to large cells. Surface assimilation numbers in the same distance decrease from 13.02 to 9.08 , but the maximum $\alpha$ estimation corresponds to Stn 65 . The assimilation number, a parameter related to algal metabolism, is likely to vary between early and late stages of an algal bloom as nutrient concentrations change (Wilkerson \& Dugdale 1987, Dugdale \& Wilkerson 1989), while light-limited photosynthesis rates are generally less affected by nutrient limitation (Geider \& Osborne 1992). 
Zooplankton grazing could also contribute to the chlorophyll decline. Barton et al. (1998) reported high zooplankton biomass in the center of the filament coinciding with a relative minimum in chlorophyil. This zooplankton maximum can be either the manifestation of transport of organisms along the filament or the result of in situ growth in waters of high phytoplankton content.

The decrease of phytoplankton biomass along the filament and the same magnitude of shoreward recirculation as offshore jet current velocities (Barton et al. 1998) result in a negative balance between offshore and onshore transport of chlorophyll. The magnitude of the along-jet imbalance is obviously dependent upon the area considered for transport calculations. Assuming the entire jet is covered, the larger the area of the return flux considered, the greater the imbalance obtained. In any case, apart from considerations on whether the net onshore transport value is real or not, the Cabo Bojador filament was clearly acting as a recirculation loop during our study. Seaward transport mainly occurred in the mixed layer while shoreward transportation presented maxima at deeper layers.

This situation clearly differs from studies based on ocean color images (Hernádez-Guerra et al. 1993) and field data (Arísteguj et al. 1997) in the vicinity of Gran Canaria, an island $215 \mathrm{~km}$ off the upwelling, where high chlorophyll concentrations transported by filaments were observed. The nature of the filament and its genesis are critical for the biological consequences of the filament. The stage of development of the filament structure can also be important in terms of its biological consequences.

\section{Variability in photosynthetic parameters}

There is a considerable variability in the photosynthetic parameters in the Canaries region, due to the contrast between the oligotrophic surface waters of the eastern North Atlantic boundary current and the nutrient-rich upwelling waters. In the ML, extremely low $\alpha$ values were measured in the westernmost regions (G1 and G2), and the assimilation number varied by a

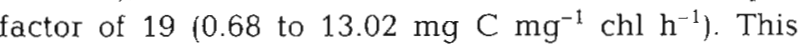
dramatic variation within a few hundred kilometers reflects the differences between 2 systems that occupy the lower and the higher extremes in the productivity range. The $P_{\mathrm{m}}$ values are similar to the range observed by Kyewalyanga et al. (1998) in a transect across the North Atlantic during spring 1993 and, similarly, low surface $\alpha$ values (<0.01) were observed by Marañon \& Holligan (1999) in a meridional transect across the Atlantic at the same latitude of the Canary Islands. Hood et al. (1991), in a survey of the CTZ off northern
California, observed significant differences in the phytoplankton P-E response curves; these were attributed to changes in the taxonomic composition, light history and physiological condition of cells. The contribution of each of these variables to photosynthetic changes in natural samples is, however, difficult to evaluate. Kennaway \& Tett (1994) observed an onshore-offshore shift in phytoplankton species composition. Upwelling waters were dominated by diatoms and haptophytes, while in more stratified waters the surface community was mainly composed of Synecoccocus and Prochlorococcus and haptophytes constituted the deep $\mathrm{cm}$.

Differences in turbulence and species composition are also responsible for vertical variations in the photosynthetic responses. Over the shelf, similar responses between ML and CM samples were measured, and no photoinhibition was observed. The lack of photoinhibition in the CM sample at Stn 56 could be the result of enhanced turbulence near the coast caused by upwelling and mixing processes. Lewis et al. (1984) reported a relationship between $\Delta P_{\mathrm{m}}$, the differences in $P_{m}$ at the surface and near the bottom of the mixed layer, and turbulent mixing rates. They argued that cells grown in turbulent waters present similar photosynthetic response due to a lack of photoadaptation. Conversely, when the rate of photoadaptation is high relative to turbulence-induced light fluctuation, differences in $P_{m}$ appear. These differences are magnified at larger depth scales. Stratification beneath the pycnocline generates nutrient and light availability gradients where phytoplankton species composition and physiology vary. The rate of photoadaptation is likely to be high enough to overcome changes in light levels caused by vertical turbulent motions; therefore, phytoplankton cells should be well adapted. Moreover, if we consider that adaptation from high light to low light is faster than adaptation from low light to high light (Cullen \& Lewis 1988), we could presume that slowly falling phytoplankton cells would easily adapt to progressively decreasing irradiance. However, sinking phytoplankton cells do not only experience changes in irradiance but also in light quality (primarily affecting $\alpha$ ) and in nutrient availability. These factors generate different ecological niches throughout the water column which are occupied by distinct phytoplankton assemblages.

As an example, we can consider the effect of nitracline uplift in the center of the observed cyclonic eddies. The chlorophyll-specific rate of photosynthesis was clearly enhanced in these structures. There is evidence that nutrient limitation can modify photosynthesis parameters (Falkowski et al. 1985, Osborne \& Geider 1986 , Herzig \& Falkowski 1989, Platt et al. 1992, Sathyendranath et al. 1996). However, Cullen et al. (1992b), in a 
review focused on this issue, conclude that assimilation number is an unreliable diagnostic index of nutrient assimilation, and that only in laboratory cultures at controlled light and temperature conditions does low $P_{\mathrm{m}}$ imply nutritional deficiency. Therefore, increases in the photosynthetic parameters in the observed eddies may not necessarily correspond to a nutrient injection in the existing phytoplankton communities. Higher parameters in nutrient-rich waters could also be interpreted as the generation of a niche that is occupied by new communities with a different P-E performance. Falkowski et al. (1991), for an eddy in Hawaii, estimated a $67 \%$ increase in the chlorophyll-specific rate of photosynthesis and about a $20 \%$ increase in the integrated primary production compared to adjacent waters. For the same structure, Olaizola et al. (1993) reported an increase in the photosynthetic parameters in the DCM $\left(\alpha\right.$ and $P_{m}$ were 2.28 and 3.6 times higher, respectively, in the eddy than at other stations) and a change in the floristic composition. Several authors (Eppley et al. 1979, Balch et al. 1997, Maranon \& Holligan 1999) have reported relationships between the depth of the nitracline and production rates. Balch et al. (1997) observed an exponential increase in production as the pycnocline shoaled in the Californian Upwelling, which they attributed to the photon flux increase at shallower depths. They also suggested that isopycnal and diapycnal mixing of nitrate-rich water was sufficient to sustain higher primary production levels when the pycnocline shoaled. This effect is also observed in the grouped photosynthetic parameters (Table 4), which show a progressive increase as the African shelf is approached. The phytoplankton photosynthetic response and therefore primary production in the G1 zone is, however, more variable and not related to isopycnal uplifting. This variability cannot be attributed to biomass changes (average integrated chlorophyll values are only slightly lower in G1 than in G2) but, instead, must be caused by the variability of the photosynthetic performance of algae (production at G2 is almost double that at G1). Marañon \& Holligan (1999) have also addressed the importance of phytoplankton photosynthetic performance at larger scales.

\section{Regional production estimates}

Empirical relationships between chlorophyll and integrated primary production possibly offer the simplest approach to infer the productivity over vast oceanic areas (e.g. Eppley et al. 1985). With the aim of progressively attaining better estimations, these relations, the strength of which relies on their simplicity, have been implemented with more mechanistic approaches that require the introduction of physiological parameters.
These algorithms have been fragmented into relations affecting to relatively biogeochemically homogeneous ocean compartments or 'provinces'. This has accounted for inter-regional differences; however, intra-regional variability is mainly reproduced in terms of biomass variations. From our results it is evident that other factors of variation should be included in order to achieve a more realistic representation of the intra-regional variability. In the most oligotrophic zone of the surveyed area (G1), spatial primary production increases are not accompanied by proportional increases in chlorophyll. We have observed variations in the ML of almost an order of magnitude for $P_{\mathrm{m}}$ values while, surface and integrated chlorophyll remained extremely constant. As Lewis (1992) states, the high variability of physiological parameters even over short time and restricted space is still limiting these methods. Uncoupling between production and chlorophyll could be explained if: (1) subtropical plankton assemblages present high and variable C:chl ratios or (2) if microzooplankton rapidly controls the produced biomass. Maximum C:chl ratios are typical from oceanic areas experiencing high irradiance. This effect is caused by the reduction of cell pigment content at high irradiance but also by restricted nutrient availability in stratified regions. Taylor et al. (1997), based on modeled results, report highest C:chl (>150) ratios in the surface layers between 25 and 35 degrees of latitude. An alternative, but not excluding, explanation is a zooplankton control over the newly produced biomass. A coupled phytoplankton-herbivore system in which grazing limits the standing crop has been suggested as an explanation for open ocean high-nutrient low-chlorophyll situations (Walsh 1976, Minas et al. 1986, Cullen et al. 1992a), but could also be applicable for most subtropical areas. In these regions mesoscale and smaller scale physical processes would control productivity.

In conclusion, our results show that transition zones between highly productive upwelling systems and oligotrophic open ocean waters present a large variability in photosynthetic parameters. Unless this variability is considered in productivity models, regional production estimations can be greatly biased.

Acknowledgements. We wish to thank Dr E. D. Barton for his helpful comments and corrections, and the crew and technical staft of the BIO 'Hesperides' for their invaluable help during the cruise. This work was supported by project FRENTES (CICYT, AMB 95-0731), and through MAST I Program 0031 and the CANIGO program of the European Commission.

\section{LITERATURE CITED}

Abbott MR, Zion PM (1985) Satellite observations of phytoplankton variability during an upwelling event. Contin Shelf Res 4:661-680 
Abbott MR, Brink KH, Booth CR, Blasco D, Codispoti LA, Niiler PP, Ramp SR (1990) Observations of phytoplankton and nutrients from a Lagrangian drifter off northern California. J Geophys Res 95(C6):9393-9409

Arístegui J, Sangrá P, Hernández-León S, Cantón M, Hernández-Guerra A, Kerling JL (1994) Island-induced eddies in the Canary Islands. Deep-Sea Res 41:1509-1525

Arístegui $J$, Tett $P$, Hernández-Guerra $A$, Basterretxea $G$, Montero MF, Wild K, Sangrá P, Hernández-León S, Cantón M, García-Braun JA, Pacheco M, Barton ED (1997) The influence of island-generated eddies on chlorophyll distribution: a study of mesoscale variation around Gran Canaria. Deep-Sea Res 44(1):71-96

Austin RW (1974) The remote sensing of spectral radiance from below the ocean surface. In: Jerlov NG, Nielsen ES (eds) Optical aspects of oceanography. Academic Press, San Diego, CA, p 317-344

Balch WM, Byrne CF (1994) Factors affecting the estimate of primary production from space. J Geophys Res 99(C4): $7555-7570$

Balch WM, Bowler BC, Byrne CF (1997) Sea surface temperature gradients, baroclinicity, and vegetation gradients in the sea. J Plankton Res 19(12):1829-1858

Barber RT, Smith RL (1981) Coastal upwelling ecosystems. In: Longhurst AR (ed) Analysis of marine ecosystems. Academic Press, London, p 31-68

Barton ED (1994a) Frontal structures downwind and downstream of Gran Canaria. Ann Geophysicae 12(II), C267

Barton ED (1994b) European Coastal Transition Zone: Islas Canarias. Final Report, MAST Project 0031, European Commission, Bangor

Barton ED, Arístegui $\mathrm{J}$, Tett $\mathrm{P}$, Cantón M, García-Braun $\mathrm{J}$, Hernández-León $\mathrm{S}$, Nykjaer $\mathrm{L}$, Almeida $\mathrm{C}$, Almunia $\mathrm{J}$, Ballesteros S, Basterretxea G, Escánez J, García-Weill L, Hernández-Guerra A, López-Laatzen F, Molina R, Montero MF, Navarro-Pérez E, Rodriguez-Pérez JM, van Lenning $K$, Vélez H, Wild K (1998) The transition zone of the Canary Current upwelling region. Prog Oceanogr 41(4):455-504

Behrenfeld MJ, Falkowski PG (1997a) Photosynthetic rates derived from satellite-based chlorophyl concentration. Limnol Oceanogr 42(1):1-20

Behrenfeld MJ, Falkowski PG (1997b) A consumer's guide to phytoplankton primary productivity models. Limnol Oceanogr 42(7):1479-1491

Bidigare RR, Smith RC, Baker KS, Marra J (1987) Oceanic primary production estimates from measurements of spectral irradiance and pigment concentrations. Global Biogeochem Cycles 1:171-186

Bidigare RR, Prézelin BB, Smith RC (1992) Bio-optical models and the problems of scaling. In: Falkowski PG. Woodhead $\mathrm{AD}$ (eds) Primary productivity and biogeochemical cycles in the sea. Environmental Science Research, Vol 143 Plenum Press, New York, p 175-212

Brink KH, Beardsley RC, Niller PP, Abott M, Huyer A, Ramp S, Stanton T, Stuart D (1991) Statistical properties of nearsurface flow in the California coastal transition zone. J Geophys Res 96(C8):14693-14706

Cullen JJ, Eppley RW (1981) Chlorophyll maximum layers off the southern California bight and possible mechanisms of their formation and maintenance. Oceanol Acta 4:23-32

Cullen JJ, Lewis MR (1988) The kinetics of algal photoadaptation in the context of vertical mixing. J Plankton Res 10(5):1039-1063

Cullen JJ, Lewis MR, Davis CO, Barber RT (1992a) Photosynthetic characteristics and estimated growth rates indicate grazing is the proximate control of primary production in the Equatorial Pacific. J Geophys Res 97:639-654
Cullen JJ, Yang X, MacIntyre HL (1992b) Nutrient limitation of marine photosynthesis. In: Falkowski PG, Woodhead AD (eds) Primary productivity and biogeochemical cycles in the sea. Plenum Press, New York, p 69-88

Davis RE (1985) Drifter observations of coastal surface currents during CODE: the method and descriptive view. J Geophys Res 90:4741-4755

Dugdale RC, Wilkerson FP (1989) New production in the upwelling center of Point Conception, California: temporal and spatial patterns. Deep-Sea Res 36:985-1007

Eppley RW, Peterson BJ (1979) Particulate organic matter flux and the planktonic new production in the deep ocean. Nature 282:677-680

Eppley RW, Renger EH, Harrison WG (1979) Nitrate and phytoplankton production in southern California coastal waters. Limnol Oceanogr 24:291-301

Eppley RW, Stewart E, Abbott MR, Heyman U (1985) Estimated ocean primary production from satellite chlorophyll. Introduction to regional differences and statistics from Southern California Bight. J Plankton Res 7:57-70

Falkowski PG, Dubinsky Z, Wyman K (1985) Growth-irradiance relationships in phytoplankton. Limnol Oceanogr 30 . $311-321$

Falkowski PG, Ziemann D, Kolber Z, Bienfang PK (1991) Role of eddy pumping in enhancing primary production in the ocean. Nature 352:55-58

Flament $\mathrm{P}$, Armi L, Washburn L (1985) The evolving structure of an upwelling filament. J Geophys Res 90:11765-11778

Geider RJ, Osborne BA (1992) Algal photosynthesis: the measurement of algal gas exchange. Chapman and Hall, New York

Gordon HR, Clark DK, Mueller JL, Hovis WA (1980) Phytoplankton pigments from the Nimbus- 7 Coastal Zone Color Scanner: comparisons with surface measurements. Science 210:63-66

Haynes R, Barton ED, Pilling I (1993) Development, persistence, and variability of upwelling filaments off the Atlantic coast of the Iberian Peninsula. J Geophys Res 98(C12):22681-22692

Herbland A, Voituriez B (1979) Hydrological structure analysis for estimating the primary production in the Tropical Atlantic Ocean. J Mar Res 37:87-101

Hernández-Guerra A, Aristegui J, Cantón M, Nykjaer L (1993) Phytoplankton pigment patterns in the Canary Islands area as determined using Coastal Zone Colour Scanner data. Int J Remote Sensing 14(7):1431-1437

Herzig R, Falkowski PG (1989) Nitrogen limitation in Isochrysis galbana (Haptoficeae). I. Photosynthetic energy conversion and growth efficiencies. J Phycol 25:462-471

Holm-Hansen O, Lorenzen CJ, Holmes RW, Strickland JDH (1965) Fluorometric determination of chlorophyll. J Cons Int Explor Mer 30:3-15

Hood RR, Abbott MR, Huyer A (1991) Phytoplankton and photosynthetic light response in the coastal transition zone off northern California in June 1987. J Geophys Res 96(C8): $14769-14780$

Huyer A, Kosro PM (1987) Mesoscale surveys over the shelf and slope in the upwelling region near Point Arena, California. J Geophys Res 92:1655-1681

Jones BH, Mooers CNK, Rienecker MM, Stanton T, Washburn L (1991) Chemical and biological structure and transport of a cool filament associated with a jet-eddy system off northern California in July 1986 (OPTOMA21). J Geophys Res 96(C12):22207-22225

Kelly KA (1985) The influence of winds and topography on the sea surface temperature patterns over the northern California slope. J Geophys Res 90:11783-11798 
Kennaway GM. Tett P (1994) A scanning electron microscope study of flagellate assemblies from the Hespérides Cruise 9308. Data Report 0031-17. School of Ocean Sciences, University of Wales, Bangor

Kiefer DA, Mitchell BG (1983) A simple steady state description of phytoplankton growth based on absorption cross section and quantum efficiency. Limnol Oceanogr 28: $770-776$

Koblents-Mishke OI (1983) An attempt to classify the marine pelagic ecosystems on the basis of primary production and its spatial variability. Oceanology 23 2$\}: 233-239$

Kosro PM, Huyer A, Rampt SR, Smith RL, Chavez FP, Cowles TJ, Abbott MR, Strub PT, Barber RT, Jessen P, Small LF (1991) The structure of the transition zone between coastal waters and the open ocean off northern California, winter and spring 1987. J Geophys Res 96(C8):14707-14730

Kostianoy AG, Zatsepin AG (1996) The West African coastal upwelling filaments and cross-frontal water exchange conditioned by them. In: Dejenidi S (ed) The coastal ocean in a global change perspective. J Mar Syst 7:349-359

Kyewalyanga MN, Platt $T$, Sathyendranath $S$, Lutz VA, Stuart $V(1998)$ Seasonal variations in physiological parameters of phytoplankton across the North Atlantic. J Plankton Res 20(1):17-42

La Violette PE (1974) A satellite-aircraft thermal study of the upwelled waters off Spanish Sahara. J Phys Oceanogr 4(4):674-684

Lewis MR (1992) Satellite ocean color observations of global biogeochemical cycles. In: Falkowski PG. Woodhead AD (eds) Primary productivity and biogeochemical cycles in the sea. Plenum Press, New York, p 139-153

Lewis iviR, Sninih JC (1983) A snall volunte, shori-incuidatiuntime method for measurement of photosynthesis as a function of incident irradiance. Mar Ecol Prog Ser 13:99-102

Lewis MR, Horne EPW, Cullen JJ, Oakey NS, Platt T (1984) Turbulent motions may control phytoplankton photosynthesis in the upper ocean. Nature 311(5981):49-50

Longhurst A (1995) Seasonal cycles of pelagic production and consumption. Prog Oceanogr 36:77-167

MacCaull WA, Platt T (1977) Diel variations in the photosynthetic parameters of the coastal marine phytoplankton. Limnol Oceanogr 23:723-731

Maranion E, Holligan PM (1999) Photosynthetic parameters of phytoplankton from $50^{\circ} \mathrm{N}$ to $50^{\circ} \mathrm{S}$ in the Atlantic Ocean. Mar Ecol Prog Ser 176:205-214

Margalef R (1982) Ecología. Omega, Barcelona

Marra J (1980) Vertical mixing and primary production. In: Falkowski PG (ed) Primary productivity in the sea. Environmental Science Research, Vol 19. Plenum Press, New York, p 121-137

Minas HJ, Minas M. Packard TT (1986) Productivity in upwelling areas deduced from hydrographic and chemical fields. Limnol Oceanogr 31:1182-1206

Mooers CNK, Robinson AL (1984) Turbulent jets and eddies in the California Current and inferred cross-shore transports. Science 223:51-53

Navarro-Pérez E, Barton ED (1998) The physical structure of an upwelling filament of the north-west African coast during August 1993. In: Pillar SC, Moloney CL, Payne AIL, Shillington FA (eds) Benguela dynamics: impacts of variability on shelf-sed environments and their living resources. S Air J Mar Sci 19:61-74

Olaizola M, Zjemann DA, Bienfang PK, Walsh WA, Conquest LD (1993) Eddy-induced oscillations of the pycnocline affect the floristic composition and depth distribution of phytoplankton in the subtropical Pacific. Mar Biol 116: $533-542$
Osborne BA, Geider RJ (1986) Effects of nitrate limitation on photosynthesis in the diatom Phaeodactilum tricornutum Bohlin (Bacillariophyceae). Plant Cell Environ 9:617-625

Platt T, Gallegos CL, Harrison WG (1980) Photoinhibition of photosynthesis in natural assemblages of marine phytoplankton. J Mar Res 38:687-701

Platt T, Sathyendranath S, Caverhill C, Lewis MR (1988) Oceanic primary production and available light: Further algorithms for remote sensing. Deep-Sea Res 35:855-879

Platt T, Caverhill C, Sathyendranath S (1991) Basin-scale estimates of oceanic primary production by remote sensing: The North Atlantic. J Geophys Res 96:15147-15159

Platt $T$, Sathyendranath S, Ulloa O, Harrison WG. Hoepffner N, Goes J (1992) Nutrient control of phytoplankton photosynthesis in the Western North Atlantic. Nature 356: $229-231$

Rienecker MM, Mooers CNK, Hagan DE, Robinson AL (1985) A cool anomaly off northern California: an investigation using IR imagery and in situ data. J Geophys Res 90: $4807-4818$

Sathyendranath S, Platt T, Horne EPW, Harrison WG, Ulloa O, Outerbridge R, Hoepffner N (1991) Estimation of new production in the ocean by compound remote sensing Nature 353:129-133

Sathyendranath S, Longhurst A, Caverhill CM, Platt T (1995) Regionally and seasonally differentiated primary production in the North Atlantic. Deep-Sea Res 42(10): 1773-1802

Sathyendranath S, Platt T, Stuart V, Irwin B, Veldhuis MJW, Kraay GW, Harrison WG (1996) Some bio-optical characteristics of phytoplankton in the NW Indian Ocean. Mar Ecol Prog Ser 132:299-31 i

Shannon LV, Walters NM, Mostert SA (1985) Satellite observations of surface temperature and near-surface chlorophyll in the southern Benguela region. In: Shannon LV (ed) South African Ocean Color and Upwelling Experiment. Sea Fisheries Research Institute, Cape Town, p $183-210$

Strub PT, Kosro PM, Huyer A (1991) The nature of cold filaments in the California current system. J Geophys Res 96(C8):14743-14768

Swenson MS, Niiler PP, Brink KH, Abbott MR (1992) Drifter observations of a cold filament off Point Arena, California, in July 1988. J Geophys Res 97(C3):3593-3610

Taylor AH, Geider RJ, Gilbert FJH (1997) Seasonal and latitudinal dependencies of phytoplankton carbon-to-chlorophyll a ratios: results of a modelling study. Mar Ecol Prog Ser 152:51-66

Traganza ED, Nestor DA, McDonald AK (1980) Satellite observations of a nutrient upwelling off the coast of California. J Geophys Res 85:4104-4106

Van Camp L, Nykjaer L, Mittelstaedt E, Schlittenhardt P (1991) Upwelling and boundary circulation off Northwest Africa as depicted by infrared and visible satellite observations. Prog Oceanogr 26:357-402

Venrick EL, McGowan JA, Mantyla AW (1973) Deep maxima of photosynthetic chlorophyll in the Pacific Ocean. Fish Bull US 71:41-52

Walsh JJ (1976) Herbivory as a factor in patterns of nutrient utilization in the sea. Limnol Oceanogr 21:1-13

Webb WL, Newton M, Starr D (1974) Carbon dioxide exchange of Alnus rubra: a mathematical model. Oecologia $17: 281-291$

Wilkerson FP, Dugdale RC (1987) The use of large shipboard barrels and drifters to study the effects of coastal upwelling on phytoplankton dyramics. Limnol Oceanogr 32: $368-382$ 